\title{
FÓRUM
}

\section{Hausner Gábor^^}

\section{Zrínyi 400}

\section{A katona-hadtudós Zrínyi Miklós emlékezete a Magyar Honvédségben}

DOI 10.17047/HADTUD.2021.31.4.118

A Magyar Országgyúlés 2019. december 11-én elfogadott határozata a költô, hadvezér és hadtudós Zrínyi Miklós (1620-1664) születésének 400. évfordulója alkalmából a 2020-as esztendốt Zrínyi Miklós Emlékévvé nyilvánította. A COVID-19 koronavírus járvány miatti vészhelyzet a tervezett rendezvények és megemlékezések megtartásának java részét nem, vagy csak 2021-re áthúzódva tette lehetôvé, az évforduló mégsem múlt el nyomtalanul. A tanulmány röviden vázolja a Zrínyiról napjainkban folytatott tudományos diskurzus fó irányait és hangsúlyait, a civil-szakmai társadalomnak az évfordulóhoz kapcsolódó kezdeményezéseit, majd részletesen bemutatja a Zrínyi Emlékév keretében a Magyar Honvédség, a Honvédelmi Minisztérium és a Nemzeti Közszolgálati Egyetem Hadtudományi és Honvédtisztképző Kar, valamint a Magyar Hadtudományi Társaság szervezésében, támogatásával megvalósult projekteket.

KULCSSZAVAK: Zrínyi Miklós, emlékév, emlékezetpolitika, Magyar Honvédség, NKE Hadtudományi és Honvédtisztképző Kar, Magyar Hadtudományi Társaság

\section{Zrínyi 400}

\section{The Memory of the Soldier and Military Scientist Miklós Zrinyi} in the Hungarian Defence Forces

On $11^{\text {th }}$ December 2019, the National Assembly unanimously approved Parliament Resolution 51/2019 on declaring 2020 a commemorative year of warlord and military scientist Miklós Zrinyi (1620-1664) on the occasion of the 400 th anniversary of his birth. Although the emergency caused by the COVID-19 coronavirus pandemic did not allow for much of the planned events and commemorations to be held, or they were delayed until 2021, the anniversary did not pass unnoticed. This study briefly outlines the main directions and key points of the current scientific discourse on Zrinyi, the relating initiatives of the civil-professional society, and then presents in detail the projects organized and supported by

४ Nemzeti Közszolgálati Egyetem, Hadtudományi és Honvédtisztképző Kar University of Public Service, Faculty of Military Sciences and Officer Training; e-mail: hausner.gabor.laszlo@uni-nke.hu; https://orcid.org/0000-0002-4837-5149 
the Hungarian Defence Forces, the Ministry of Defence, the Faculty of Military Science and Officer Training of the National University of Public Service, and the Hungarian Association of Military Science.

KEYWORDS: Miklós Zrínyi, commemorative year, memory policy,

Hungarian Defence Forces, NUPS Faculty of Military Science and Officer Training,

Hungarian Association of Military Science

\section{Bevezetés}

A Magyar Országgyúlés 2019. december 11-én elfogadott 51/2019. határozata Zrínyi Miklós (1620-1664) születésének 400. évfordulója alkalmából a 2020-as esztendót Zrínyi Miklós Emlékévvé nyilvánította. ${ }^{1}$ A képviselók egyhangúlag, 169 igen szavazattal fogadták el a Németh Szilárd, a Honvédelmi Minisztérium parlamenti államtitkára által elóterjesztett határozati javaslatot, az indoklás szerint „tisztelettel adózva a magyar nemzetért tett hadvezéri, hadtudományi, költói és politikai munkásságának, valamint erófeszítéseinek".

Az Országgyúlés határozata kinyilvánította, hogy az emlékév keretében „támogatja és szorgalmazza a Kárpát-medence és a diaszpóra magyarsága körében olyan rendezvények, megemlékezések szervezését, valamint tudományos és ismeretterjesztó kiadványok, filmek, illetve oktatási anyagok készítését, amelyek méltó emléket állítanak Zrínyi Miklósnak és munkásságának." Jóllehet a COVID-19 koronavírus járvány miatti vészhelyzet a tervezett rendezvények és megemlékezések megtartásának java részét nem tette lehetôvé, az évforduló mégsem múlt el nyomtalanul.

Az alábbiakban röviden érintem a Zrínyiról napjainkban folytatott tudományos diskurzus fó irányait és hangsúlyait, a civil-szakmai társadalomnak az évfordulóhoz kapcsolódó kezdeményezéseit, majd bemutatom a Zrínyi Emlékév keretében a Magyar Honvédség, a Honvédelmi Minisztérium és a Nemzeti Közszolgálati Egyetem Hadtudományi és Honvédtisztképzó Kar, valamint a Magyar Hadtudományi Társaság szervezésében, támogatásával 2020-ban és 2021-ben megvalósult projekteket.

\section{A költó-író, államférfi és katona Zrinyi képe az évforduló tükrében}

Zrínyi Miklósnak a magyar nemzeti kánonban rögzült jelzói - „politikus, költő és hadvezér" - arra utalnak, hogy életmúve különbözó területeket egyesít: a halála óta eltelt három és fél évszázad során hol az egyikre, hol a másikra esett nagyobb hangsúly, de soha nem lehetett figyelmen kívül hagyni személyiségének ritka sokoldalúságát. A Zrínyiról kialakult kép az utóbbi másfél évtizedben több vonatkozásban is a paradigmaváltás jeleit mutatja.

Az irodalomtörténeti kutatások már régen rámutattak Zrínyi Miklós költői munkásságának egyszerre archaizáló és innovatív jellegére; viszont csak most kezd kellő figyelmet kapni a Zrínyi-fivérek európai szinten is unikumnak számító tudatos együttmúködése, a horvát és a magyar, a mediterrán és a közép-európai kultúrák közötti fordítói-mediátori vállalkozásának jelentósége. A magyar és a horvát

1 Az Országgyúlés 51/2019. (XII. 12.) OGY határozata. Magyar Közlöny 2019 (201): 8794. 
(Zrínyi Péter által lefordított és 1660-ban megjelentetett) Syrena-kötetek összehangolt koncepciója világosan mutatja, hogy a Zrínyiek nem statikus nemzetkép(ek)ben gondolkodtak, hanem lojalitásaikat és identitásaikat egymáshoz képest, dinamikusan definiálták. ${ }^{2}$

Zrínyi Miklós születésének 400. évfordulójára az irodalomtörténészek újabb tudományos eredményekkel gazdagították a Zrínyi-képet. Az évfordulóhoz kapcsolódó egyetlen nagyobb, országos konferenciát is ók rendezték "Zrínyi Miklós és a magyar barokk költészet" címmel az egri Eszterházy Károly Egyetem Irodalomtudományi Tanszéke és az Eötvös Loránd Kutatási Hálózat Bölcsészettudományi Kutatóközpont Irodalomtudományi Intézet Reneszánsz Osztálya közös szervezésében, 2020. szeptember 3-5. között Egerben. Az elóadók mintegy negyede Zrínyi irodalmi múveit történeti poétika szempontrendszerben vizsgálta, különösen a költôi múvek formai megoldásai, forrásai és egyes alkotások értelmezése állt érdeklődésük középpontjában, de fontos észrevételek születtek a két Zrínyi Miklós (a szigetvári hôs és a költő, hadvezér) politikai utóéletéról, a magyar és a (pán)szláv nemzeti ideológiákban betöltött szerepükról. 2021-ben az elhangzott elóadások szerkesztett szövegei is megjelentek egy több mint félezer oldalas tanulmánykötetben. ${ }^{3} \mathrm{Az}$ egri konferencia két előadója, egyúttal mindkettő az említett tanulmánykötet szerzóje, önálló Zrínyi-kötettel is jelentkezett utóbb.

Suhai Pál, aki Egerben egy új, mai alakra átírt szövegú Zrínyi kiadás alapelveiról és nehézségeiról tartott elóadást, 2020 végén a teljes életmúvet bemutató, értelmezó olvasókönyvet nyújtott át a tanulóifjúság és a tanárok számára, fogalmazása szerint: „ünneppé és programmá tenni azok számára is Zrínyi örökségét, akik első ránézésre talán megriadnának tekintetétól." 4

Egy igazi paradigmaváltó, alapmú is született az évforduló vonzásában, Bene Sándor, a Károli Gáspár Egyetem és a Zágrábi Tudományegyetem egyetemi docense, az Eötvös Loránd Kutatási Hálózat Bölcsészettudományi Kutatóközpont Irodalomtudományi Intézetének munkatársa 2021 végén, az Osiris Kiadó irodalomtörténeti sorozatában megjelent monográfiája Zrínyi Miklós költészetéról. ${ }^{5}$ A terjedelmét és a megmozgatott anyagot tekintve is hatalmas munka (a kötet végén található irodalomjegyzék több mint 80 oldalon sorolja a felhasznált szakirodalmat és forrásokat!) átfogó értékelésére nem vállalkozhatok, de az bizton kijelenthetô, hogy Klaniczay Tibor Zrínyi-monográfiájának 1964-es második kiadása óta ${ }^{6}$ ez a legjelentősebb Zrínyi-értelmezés, amely új megvilágításba állítja az életmúvet. A könyv a szerző

2 Lásd ezek legújabb összefoglalását: Hausner 2016 és Bene, Fodor, Hausner, Padányi 2017.

3 Bene, Pintér 2021.

4 Suhai 2020, 14. A 678 oldalas kötet tartalmazza a költói és a prózai múvek bőséges szemelvényeinek modernizált szövegkiadását. Az ezt követő fejezetek (szöveggyújtemény a világirodalmi és magyar irodalmi példákkal és párhuzamokkal, majd a "Szigeti veszedelem és írója” címú tanulmány, végül egy gazdagon illusztrált múvelődéstörténeti fejezet a Zrínyi múvek múvelődéstörténeti vonatkozásairól) a Zrínyi múvek rejtelmeibe avatják be az olvasót, megkönnyítendó a tájékozódást és az eligazodást az életmúben.

5 Bene 2021. A monográfia megjelenése eredetileg 2020-ra volt tervezve, de munkálatai egyebek között a pandémia miatt elhúzódtak.

6 Klaniczay 1964. 
bevezetóje szerint nem Zrínyi-monográfia, „hanem a Syrena-kötet összehasonlító történeti poétikai vizsgálata, hosszú esszé az irodalmi modernség tradíciójáról arról, ami maradt és arról, ami kihullott a hagyományból." ${ }^{\prime 7}$ Mint a fenti idézetból is kiolvasható, Bene mondanivalójának egyik újdonsága, hogy szerinte „Zrínyi Miklós az elsố modern magyar költô." Ennek az állításnak a lenyúgözố erudícióval való bizonyítása mellett a kötet másik nóvuma a nemzeti hovatartozás, a "magyarság” kérdésének a horvát narratívákkal való összehasonlító vizsgálata, amelynek eredményeként fény vetül a Zrínyi-fivérek regionális kapcsolódásaira.

Ugyancsak jelentôs hozadéka Bene Sándor könyvének Zrínyi gondolkodása és politikai, irodalmi törekvései európai távlatainak és összefüggéseinek komparatív, minden korábbinál alaposabb bemutatása, valamint az 1651-ben Bécsben megjelent Adriai tengernek Syrenaia Groff Zrini Miklos címú verskötet és az első prózai mú, a Vitéz hadnagy részei egymáshoz viszonyított idôrendjének a megállapítása. Meggyôzố elemzéssel valószínúsíti, hogy a szakirodalom eddigi vélekedésével szemben a Vitéz hadnagy „,jelentốs része párhuzamosan készült a költói múvekkel - az eposz pedig elóbb íródott, mint a líra. Ettól nagyon sok minden megváltozik a kötetkompozíció értelmezésében." ${ }^{8}$

Jóllehet Bene Sándor könyve nem történeti munka, s eredendóen nem Zrínyiról, hanem a Syrena-kötetról beszél, Zrínyi személyiségrajzához is ad néhány új támpontot. Az egyik vonás, amely világosan kirajzolódik, Zrínyi, a költó magányossága. Körülötte nem volt költói mozgalom, költészete poétikai tudatosságú rétegét, amellyel messze megelőzte korát és kortársait, senki sem értette a korban. (Talán ez is egyik oka lehetett költóként korai elhallgatásának.) A másik felismerhetố személyiségjegy Zrínyi heroikus kegyelemhite. Bene ennek tulajdonítja, hogy „Zrínyi politikusnak költố volt, legalábbis részben. Új-Zrínyivárat kettôs céllal építette: a török felvonulást kívánta akadályozni - ez racionális cél volt. Másfelól viszont sorslaboratóriumnak szánta, ahol a dédapja által az eposzban (Istvánffy nyomán) megírt heroikus gesztust, a török magára húzását, a herkulesi máglya belobbantását kipróbálhatta volna. Ez utóbbit nem fogja feltárni sem ásatás, sem fémdetektoros vizsgálat. Mert nem valósult meg soha. Ám a meg nem valósult gesztusok éppúgy hozzá tartoznak egy személyiség képéhez, mint az elkövetett hibák és megfényesító erények. $S$ ha Zrínyi politikusnak kicsit költő, akkor ennek végső okát abban kereshetjük, hogy költőnek viszont teológus volt." ${ }^{9}$

Bene Sándor Zrínyi személyiségéhez tartozónak tekinti nemcsak a valóságosan betöltött funkcióit és a vele reálisan megesett dolgokat, hanem az álmait, vágyait, mindazt, amit magáról múveiben és leveleiben átadni szeretett volna, amilyennek láttatni akarta magát. Véleménye szerint ezek „sokkal magasabbra nyúltak, mint amennyit életében elérni sikerült. Amennyit reálisan tett, az messze nem mérhetố ahhoz, mint amennyit halála után másfél évszázaddal költóként elért a magyar szellemi életben. Íróként, költốként sokkal nagyobb hatást gyakorolt az utókorra, mint politikusként vagy katonaként a sajátjára."10

\footnotetext{
7 Bene 2021, 23.

8 Bene 2021, 21.

9 Bene 2021, 22.

10 Bene 2021, 20.
} 
Ezen a ponton kapcsolódik ez az alapvetôen irodalomtörténészi Zrínyi-kép az utóbbi évtizedek történettudományi narratívájához, amelyben szintén egyre nagyobb hangsúlyt kapott Zrínyi Miklós kettős, de inkább hármas, horvát, magyar és birodalmi identitása, valamint lojalitásai, a Zrínyiek nemzeti határokon átnyúló családi kapcsolatai, a birodalmi arisztokráciába integrálódásuk. Pálffy Géza, az MTA Eötvös Loránd Kutatási Hálózat Bölcsészettudományi Kutatóközpont Történettudományi Intézetének tudományos tanácsadója, a korszak és Zrínyi életmúvének egyik legkiválóbb kutatója Több ország szolgálatában - a politikus, katona és költó-iró Zrínyi Miklós identitásai címmel a Magyar Tudományos Akadémia honlapján 2020. január 21-én, mintegy az emlékév nyitányaként megjelent „vezércikkében” egyenesen Zrínyi különféle lojalitásainak gyakran feloldhatatlan összeütközésével magyarázza Zrínyi múveinek némely sajátosságát és kiemelkedő jelentőségét: „A költóként és íróként is hallatlanul tehetséges Zrínyi irodalmi identitása talán éppen amiatt annyira markáns és szenvedélyes, hadtudományi munkássága pedig egyedülálló és ambiciózus álmokkal teli [kiemelések tólem - H. G.], mert a tényleges napi politikában az említett három állam eltéró érdekei teljességgel sohasem voltak összeegyeztethetóek." Pálffy ugyancsak egyetért az irodalomtörténésszel abban, hogy az irodalmi és hadtudományi munkásság alapján „a fơméltóság, politikus és hadvezér tevékenysége nehezen vagy csak részben rekonstruálható". 11

Pálffy a levéltári és elbeszéló források alapján arra a következtetésre jutott, hogy „a politikus, katona és költô-író Zrínyi Miklós különféle lojalitásainak és identitásainak, tisztségeinek, házasságainak és birtokainak köszönhetôen egyszerre volt igen meghatározó és elismert tagja a Magyar és a Horvát Királyság, valamint a Habsburg Monarchia politikai-katonai elitjének egyaránt. Pályája érzékletesen bizonyítja, hogy a 17. század közepén a dinasztia és az uralkodó iránti húség összeegyeztethetô volt a »hazafisággal«, azaz a Magyar Királyság, a magyar és horvát »rendi nemzetek« érdekeinek védelmével és több ország szolgálatával... Ezért joggal lehet rá büszke minden magyar és horvát, sốt osztrák és közép-európai állampolgár, minden szigetvári, zágrábi vagy csáktornyai lokálpatrióta."12

A napjaink tudományos közvéleményét erőteljesen formáló történész Zrínyi katonai elképzeléseit is mérlegre tette, és több - a hadtudomány számára kiemelten fontos - témát is érintett. Elôször is a Zrínyi nevéhez évszázadok óta hozzátapadt 'költő, hadvezér, politikus' jelzók sorrendjének megváltoztatását, cseréjét javasolja, a hadvezér helyett a szerényebb 'katona' fogalmát illesztve a felsorolásba. Ez összefügg Pálffy Géza azon markáns véleményével, miszerint az oszmánok kiúzésének az 1660-as években nem volt realitása, s még ha mozgósító jellege miatt a kérdéskör a propaganda és az irodalom szintjén jelen volt is Zrínyi írásaiban, maga sem azt hirdette, képviselte, hanem az aktívabb törökellenes fellépést. Szintúgy túlzónak nevezi a korábbi szakirodalomnak azt az állítását, miszerint Zrínyi az önálló magyar hadsereg

11 https:/mta.hu/tudomany_hirei/tobb-orszag-szolgalataban-a-politikus-katona-es-kolto-iro -zrinyi-miklos-identitasai-110242 (A letöltés ideje: 2021. 08. 16.)

12 https://mta.hu/tudomany_hirei/tobb-orszag-szolgalataban-a-politikus-katona-es-kolto-iro -zrinyi-miklos-identitasai-110242 (A letöltés ideje: 2021. 08. 16.) Pálffy Géza már korábban is foglalkozott ezzel a kérdéssel: Pálffy 2007, 39-66, különösen: 52-59; Pálffy 2017, 15-26. 
megteremtését túzte ki célul, annak megvalósítása mellett érvelt munkáiban. A Habsburg uralkodók vezette államszövetségben a kül-, had- és pénzügyek a 17. században közösek voltak, azokat a bécsi központi államszervek (Udvari Haditanács, Udvari Kamara) irányították, emiatt Pálffy szerint: „önálló magyar hadseregról a kora újkor legjelesebb magyar-horvát hadtudósa reálisan nem gondolkodhatott. Sokkal inkább gondolkodott egy a törökellenes végeken bármikor bevethetô, magyar és horvát katonákból álló, állandó, mozgó haderóben..."

Pálffy tehát Zrínyi katonai-hadtudományi munkásságának értékelésében árnyalta a korábbi szakirodalom megállapításait, az ô Zrínyije nem hadvezér, inkább a végvári harcokban kiválóan helytálló katonai vezető. Ez a hadvezért a katonától megkülönböztető, több mint egy évszázadra visszanyúló diskurzus ${ }^{13}$ a Zrínyi-emlékévben felerôsödött. Pálffy ugyanis megismételte ezzel kapcsolatos véleményét a Kossuth Rádióban 2020. november 25-én elhangzott „Egyszer volt - Zrínyi Miklós költő és hadvezér" címú adásban, ${ }^{14} \mathrm{~s}$ a Zrínyi által betöltött tisztségek vizsgálata alapján újabb érveket és adatokat sorakoztatott fel mellette Végh Ferenc történész is 2021 áprilisában tartott pécsi habilitációs elóadásában és legutóbbi munkáiban, ${ }^{15}$ valamint Domokos György hadtörténész néhány tanulmányában. ${ }^{16}$

Az utóbbi évtizedben épen ez a speciálisan hadtörténeti kérdésirány hozta talán a leglátványosabb újdonságokat Zrínyivel kapcsolatban: részint az oszmán-magyar határon épült és oly sok polémia tárgyát képezó Zrínyi-Újvár helyszíni feltárásával és rá vonatkozó írott és képi források összegyújtésével és elemzésével, ${ }^{17}$ részint Zrínyi Miklós hadtudományi múveltségének szisztematikus vizsgálatával, ilyen tárgyú

13 Elsóként Rónai Horváth Jenő honvéd százados akadémiai székfoglalójában (Rónai Horváth 1889, 19.) fogalmazta meg: „Zrínyi Miklóst... joggal nevezhetjük ugyan a XVII. század egyik legügyesebb, legvitézebb s legvakmeróbb portyázó vezérének, de nem sorolhatjuk a nagy hadvezérek közé - mert erre az általa véghezvitt cselekmények föl nem jogosítanak."

14 Szerkesztő-músorvezető: Kiss Péter Ernô. Közremúködók: Bene Sándor, Pálffy Géza. https://mediaklikk.hu/kossuth-radio/cikk/2020/11/25/egyszer-volt/ (Letöltés ideje: 2021. 09. 30.) Lásd még Pálffy 2016, különösen 19-31.

15 Végh Ferenc: Zrínyi VII. Miklós (1620-1664), a katona: egy idealizált portré újrarajzolása c. habilitációs előadása, Pécsi Tudományegyetem, Bölcsészettudományi Kar, 2021. április 14. és a „Zrínyiek a határok védelmében. A muraközi uradalom hadszervezete a kora újkorban” c. habilitációs dolgozat. https://kozepkor.tti.btk.pte.hu/hu/tartalom/habilitacios_ertekezes_tezisei_dr_vegh_ferenc (Letöltés ideje: 2021. 09. 30.) Az elóadás a Zrínyi (VII) Miklós által betöltött tisztségēek vizsgálata alapján jut Zrínyi a katona portréjának árnyaltabb megítéléséhez, míg a habilitációs dolgozat és Végh újabb tanulmányai Zrínyi Péter katonai tevékenységének a korábbiaknál pozitívabb értékelésével járulnak hozzá a kiegyensúlyozottabb képhez. Végh 2017, 217-246.; Végh 2020, 805-825.

16 Domokos et al. 2019, 16-21. Domokos 2021a. https://militaria.hu/uploads/files/53369400_1636402558.pdf

Domokos 2021c. Ars Militaria blog

https://arsmilitaria.blog.hu/2021/02/22/mi_lett_volna_ha_avagy_hogyan_nem_mentette_meg _zrinyi_miklos_a_magyarorszagot_es_a_habsburg-monarchi (L̄etöltés ideje: 2022 . 01. 20.)

17 Lásd a három összefoglaló tanulmánykötetet Hausner, Padányi 2012; Hausner, Németh 2019; Hausner, Németh 2020. Valamint a teljesség igénye nélkül: Hausner, Négyesi, Padányi 2012, 189-217; Költó, Négyesi, Bertók, Padányi, Szabó 2014; Négyesi, Németh, Padányi, Szabó 2020;

Négyesi, Németh, Padányi, Szabó 2021; Bartha, Török, Barkóczy, Padányi 2020; Domokos 2021 b. https://militaria.hu/uploads/files/53369400_1636402558.pdf (Letöltés ideje: 2022. 01. 20.); Hausner, Négyesi, Padányi 2021; Domokōs 2021 b.

https://militaria.hu/uploads/files/53369400_1636402558.pdf (Letöltés ideje: 2022. 01. 20.) 
múveinek újrakontextualizálásával, keletkezési időrendjük módosításával, ${ }^{18}$ részint pedig a Montecuccolival folytatott vitájának, kettejük viszonyának árnyaltabb bemutatásával. ${ }^{19}$ Ezek eredményeként, ha a Bene által feltételezett heroikus gesztust nem is, de Zrínyi-Újvár sáncait, épületeit, infrastruktúráját, az építés fázisait, majd az 1664. júniusi ostromot sikerült rekonstruálni. A Zrínyi-Újvár kutatás sikertörténetté, a Zrínyivel kapcsolatos történeti vizsgálatok elismert, önálló területévé vált.

A vázolt kutatások nem csupán a hangsúlyokat módosították, hanem alaposan át is rajzolták a hagyományos elképzeléseket. A „magyar” Zrínyi helyett egy horvát-magyar, közép-európai és európai Zrínyi alakja bontakozik ki; az originális katonai lángelme helyett a kor hadtudományi és filozófiai irányzataiban jól tájékozódó, sok vonatkozásban éppen Montecuccoli „iskoláját” követő (ám valódi, kiemelkedő jelentőségú stratégiai feladathoz sosem jutó) hadvezért kapunk, akinek álmai és ambíciói túlterjeszkedtek (?) a korabeli realitás határain.

\section{Emlékév központi támogatás nélkül}

Zrínyi Miklós születésének 400. évfordulója alkalmat adhatott volna arra, hogy a fent vázolt, sok irányból épüló paradigma körvonalait a kutatók közössége a szélesebb közvélemény számára is láthatóvá tegye. Ez azonban elmaradt. Jóllehet a 2019. decemberi országgyúlési határozat 4. pontja kimondta: „Az Országgyúlés felkéri a Kormányt, hogy az 1-3. pontban foglaltak figyelembevételével állapítsa meg a Zrínyi Emlékévhez kapcsolódó egyes feladatokat, és azok megvalósítása érdekében tegye meg a szükséges intézkedéseket" ${ }^{20}$ sem emlékbizottságot, sem kormánymegbízottat nem állítottak az emlékév szervezésére. ${ }^{21}$ Központi pénzügyi támogatás ${ }^{22}$ és megemlékezés híján a Zrínyi Emlékév nem lett országos jelentőségú, s nem vált az egész

18 Hausner 2013; Hausner 2017.

19 Nagy, Hausner 2011; Hausner 2017; Domokos et al. 2019, 16-21.; Domokos 2021c. https://arsmilitaria.blog.hu/2021/02/22/mi_lett_volna_ha_avagy_hogyan_nem_mentette_meg _zrinyi_miklos_a_magyarorszagot_es_a_habsburg-mononarchi (Letetöltés ideje: $\overline{2} 022.01 .20$.)

20 Az Országgyúlés 51/2019. (XII. 12.) OGY határozata. Magyar Közlöny 2019 (201): 8794.

21 Szenes Zoltán épp e folyóirat lapjain állapította meg a Zrínyi Emlékév kapcsán, hogy Magyarországon „,az emlékéveknek nincsenek kötelező elóírásai, meghatározott jegyei”, beleértve a pénzügyi kereteket. Szenes 2020, 178. A Szigetvár elfoglalásának, a szigeti Zrínyi Miklós halálának 450. évfordulójáról való méltó megemlékezés érdekében 2016-ban például Emlékbizottságot hoztak létre az Emberi Eróforrások Minisztériuma irányításával, amelyben az EMMI mellett a Külgazdasági és Külügyminisztérium, a Miniszterelnökség, a Honvédelmi Minisztérium és a Nemzetgazdasági Minisztérium képviselói, valamint különböző kulturális, tudományos szervezetek és intézmények, megyei és városi önkormányzatok küldöttei vettek részt Hóvári János elnök vezetésével.

22 A kormány eredetileg 300 millió Ft-al kívánta támogatni a 2020. évi Zrínyi-évfordulós programokat, ám a járvány elleni védekezés költségeire azt még akkor elvonták, mielótt a végrehajtási rendelet megjelent volna. Összehasonlításképpen, a „Zrínyi Miklós - Szigetvár 1566 Emlékév” keretében megvalósuló programsorozathoz a kormány mintegy félmilliárd Ft költségvetési támogatást biztosított és további 580 millió Ft-ot a Forster Gyula Nemzeti Örökségvédelmi és Vagyongazdálkodási Központon keresztül a szigetvári vár fejlesztésére. 1121/2016 (III. 10.) Korm. határozat A „Zrínyi Miklós-Szigetvár 1566" emlékév megrendezésével összefüggő feladatokról. Magyar Közlöny 2016 (34.): 3738. Az ugyancsak 2020-ra meghirdetett Nemzeti Összetartozás Évéhez kapcsolódó programok lebonyolítására a kormány több mint 10 milliárd Ft-ot biztosított. 1064/2020. (II. 28.) Korm. határozat a Nemzeti Összetartozás Evve megvalósításával kapcsolatos többlettámogatásra szolgáló költségvetési elóirányzatról. 
Kárpát-medence magyarságát magával ragadó, megmozgató eseménnyé, jobbára csak szúk tudományos-szakmai köröket és helyi, lokális közösségeket érintett meg. ${ }^{23}$

A civil szférában mindössze néhány program született a 400. évfordulóra. A Nemzetstratégiai Kutató Intézet 2020. márciusban, az óvodásoktól az egyetemistákig, különbözố korcsoportok számára meghirdetett ünnepi rajz és esszépályázat egyik témájaként "Zrínyi Miklós - a költő és hadvezér" életét és munkásságát jelölte meg. ${ }^{24}$ A Magyar Múvészeti Akadémia 2020. május 3-i megemlékezésén a szervezet fótitkára elmondta, az MMA fontosnak tartja, hogy „,saját eszközeivel segítse történelmünk és irodalmunk egyik legjelesebb képviselóje emlékének ápolását. Nemes feladat, szép szolgálat Zrínyi életével, tetteivel foglalkozni". Ebból az alakalomból bejelentették, hogy szeretnének "filmet készíteni életéról”. A Mars Hungaricus címmel tervezett film az elképzelés szerint „Zrínyi Miklós téli hadjáratát feldolgozva ... Zrínyi Miklós személyiségét és hőstetteit" állította volna középpontba. Egyetlen szépséghibája, hogy az alkotás tudomásom szerint soha nem készült el. ${ }^{25}$ Elkészült viszont a Zrínyi Miklós ravatala fölött címú 10 perces kosztümös történelmi kisfilm az Élő történelem másként - múzeumok a virtuális térben címú mintaprogram kereteiben, és a Magyar Nemzeti Múzeum honlapján 2020. november 18-án, Zrínyi halálának az évfordulóján be is mutatták az alkotókkal és a történész szakértôvel folytatott beszélgetést követóen. ${ }^{26}$

Végül még egy nemzetközi kiállítást lehet megemlíteni, amely távolról kapcsolódik Zrínyi Miklóshoz, de nem a 400. évfordulóra készült. Ez pedig az Ars et virtus Horvátország-Magyarország - 800 év közös kulturális öröksége címmel 2020 szeptemberében

Magyar Közlöny 2020 (31): 1101. A 2021. évi Benyovszky Emlékév programjainak megvalósítását, amelyet Benyovszky Móric világutazó születésének 280., halálának 235. évfordulója (!) alkalmából rendeztek a Magyar Kormány Kiemelt Nemzeti Évfordulók Bizottságának döntése alapján, a Nemzeti Kulturális Alap több mint 15 millió Ft-os támogatása tette lehetóvé (nka.hu). A Petófi Sándor születésének bicentenáriuma alkalmából meghirdetett 2022-2023-as Petőfi-emlékévre pedig a kormány 9 millárd Ft-ot biztosít, amiból 3 milliárd jut a bicentenáriumi programokra, irodalmi emlékházak és emlékhelyek fejlesztésére.

https://kormany.hu/hirek/petofi-emlekev-a-kormany-9-milliard-forintos-tamogatast-biztosit (A letöltés ideje: 2021. 08. 16.)

23 Tartottak ünnepi emlékezést, tanácskozást, koszorúzást egyebek között Szigetváron, Nagykanizsán, Zalaegerszegen, Székesfehérváron. Utóbbiról lásd Négyesi Lajos tanulmányát folyóiratunk jelen számában 135-152. oldalon. Ezeket a helyi eseményeket nem kívánom részletezni.

$24 \mathrm{mhttps} / /$ hungarianhub.com/listing/unnepi-rajz-es-esszepalyazat-a-magyar-zaszlo-es-cimer -megunneplesere-nemzetstrategiai-kutatointezet/ (A letöltés ideje: 2021. 08. 16.) Igaz a díjazottak egyik korcsoportjában sem találunk olyat, aki Zrínyi témában pályázott. http://nski.hu/dijazottak.html (A letöltés ideje: 2022. 01. 20.)

25400 éve született Zrínyi Miklós - a Múvészeti Akadémia megemlékezése. 2020. május 3. https://www.mma.hu/rendezvenyeink?p_p_id=eventdetailedportlet_WAR_mmaportlet (A letöltés ideje: 2022. 01. 20.) A teljes igazsághoz hozzá tartozik, hogy az MMA utóbb, 2021-ben 11 millió Ft-al támogatta A Zrínyiek századai (Kézzelfogható hadtörténelem) címú dobozkönyv megjelenését (Budapest: Zrínyi Kiadó, 2021.).

$26 \mathrm{https} / / \mathrm{mnm} . \mathrm{hu} / \mathrm{hu} / \mathrm{esemenyek/muzeumi-elet/filmbemutato-zrinyi-miklos-ravatala-folott}$ -elo-tortenelem-virtualis-terben (Letöltés ideje: 2022. 01. 20.) A filmet Bárány Dániel és Bárány Krisztián rendezte és a Filmever Stúdió készítette. A történész szakértó Szvitek Róbert volt. 2020. december 11-én a Magyar Nemzeti Múzeum facebook oldalán élő közvetítésben kerekasztal beszélgetésre került sor Szvitek Róbert és Végh Ferenc történészek részvételével Zrínyi Miklós halálának körülményeiról https://mnm.hu/hu/esemenyek/kiallitas/kerekasztal-beszelgetes-zrinyi-miklos-halalanak-korulmenyeirol (Letöltés ideje: 2022. 01. 20.) 
nyílt kiállítás Zágrábban a Magyar Nemzeti Múzeum és a Klovicevi Dvori Galéria közös rendezésében, ennek tárlóiban több, a Zrínyiekhez köthetố emléket is kiállítottak. $^{27}$

Ez utóbbi, közös horvát-magyar rendezésú tárlat jól mutatja, milyen lehetôségek nyilhattak volna a két ország és a két nemzet együttmúködésére a Zrínyi Emlékév kapcsán. Ahogyan az 51/2019. (XII. 12.) országgyúlési határozat fogalmazta: „Az Országgyúlés hangsúlyozza, hogy Zrínyi Miklós kiemelkedő szerepet játszott a magyar-horvát közös történelmi múlt kulcsfontosságú eseményeiben, ezért az emlékév egyben a magyar-horvát kétoldalú kapcsolatok elmélyítésének is méltó eszköze."28

\section{A katona és hadtudós emlékezete a Magyar Honvédségben}

A Zrínyi Emlékév határozattervezetét a Honvédelmi Minisztérium parlamenti államtitkára nyújtotta be az Országgyúlésnek és vitte sikerre a 2019 évi szavazás során. Ennek megfelelóen Zrínyi emlékének ápolásában, az emlékév programjainak szervezésében a legnagyobb aktivitást a Magyar Honvédség, a Honvédelmi Minisztérium és alárendelt szervezetei, valamint a hozzájuk kötődő szakmai társadalmi szervezetek mutatták, köztük a Magyar Hadtudományi Társaság.

A végrehajtott feladatok szemléje elótt szólni kell arról, mit jelent Zrínyi nekünk, katonáknak. Zrínyi az utókor honvédői szemében a magyar katona eszményét testesítette és testesíti meg napjainkban is. ${ }^{29}$ Kultusza a magyar haderóben a 18. századtól töretlen. Míg katonai teljesítményét már életében is megbecsülték, hadtudományi munkáit csak a 19. században fedezték fel, és az 1850-es évek elején jelentek meg először nyomtatásban. ${ }^{30}$ A hadtudós életmúvének jelentôségét a katonai hivatást teljesítók számára Rónai Horváth Jenó honvéd százados (utóbb altábornagy), a Magyar Tudományos Akadémia tagja 1891-ben Zrínyi hadtudományi munkái elé írt bevezetőjében fogalmazta meg, mondván Zrínyi munkáit nem szabad „egyszerú irodalmi emléknek tekintenünk; becses múvek ezek, amelyekból a mai hadseregek tisztjei is sokat, igen sokat tanulhatnak. Tanulhatnak elveket, melyeknek ismerete a katonai hivatás teljesítésére ma is nélkülözhetetlen, de tanulhatnak különösen hazaszeretetet, mely Zrínyi egész lelkét betöltötte, s átszivárgott munkáiba is." ${ }^{31}$ Ezért a Honvédség megalakulása óta nemcsak hagyományápolás és a nemzeti identitás megórzése céljából emlékezik Zrínyire, hanem a katonai oktatásban és képzésben is felhasználja és a gyakorlatban is kamatoztatja hadtudományi munkáit. Nem véletlen, hogy a felsófokú magyar tisztképzó intézmények 1950-tól napjainkig szinte megszakítás nélkül a katona és hadtudós nevét (Zrínyi Miklós Katonai Akadémia, Zrínyi Miklós Nemzetvédelmi Egyetem, Zrínyi Miklós Laktanya és Egyetemi Campus) és szellemiségét hordozták. Ezt fejezte ki az a gesztus, hogy a Honvédelmi Minisztérium kezdeményezésére,

27 Ez a tárlat elóbb virtuális kiállításként, 2021. december 10. óta időszaki kiállításként a Magyar Nemzeti Múzeumban látható. https://mnm.hu/hu/kiallitasok/idoszaki/ars-et-virtus (Letöltés ideje: 2022. 01. 20.)

28 Az Országgyúlés 51/2019. (XII. 12.) OGY határozata. Magyar Közlöny 2019 (201): 8794.

29 Harai 2017.

30 Hausner 2013, 116-130.

31 Rónai Horváth 1891, 60. Bevezetés. Zrínyi Miklós mint hadvezér és mint hadtudományi író. 
a felavatott hadnagyok 2020-ban az eskühöz használt szablya mellé, mintegy útravalóként és „iránymutatásként” megkapták Zrínyi Vitéz hadnagy címú múvének erre az alkalomra készült példányát Benkó Tibor honvédelmi miniszter előszavával. ${ }^{32}$

Az irodalomtörténészek, történészek, a civil hadtörténészek által Zrínyiról alkotott (fentebb ismertetett) kép féloldalas a katonai gondolkodók és a katonai vezetók Zrínyi-értelmezése, hadtudományi munkáinak értékükön becslése nélkül. ${ }^{33}$ A Zrínyi születésének 400. évfordulójára a Nemzeti Közszolgálati Egyetem Hadtudományi és Honvédtisztképzó Karán készült tanulmánykötetból ${ }^{34}$ jól látszik, hogy a Magyar Honvédség parancsnoka és a Ludovika-zászlóalj parancsnoka, a napjaink katonai vezetôi elé a küldetésorientált vezetés, a „mission command” és a kiszámíthatatlan, komplex jellegú VUCA-környezet ${ }^{35}$ által támasztott követelményeknek megfelelő, összetett, új gondolkodásmód kialakításában hasznosíthatónak tartja Zrínyinek a parancsnok helyéról, szerepéról, tulajdonságairól, kompetenciáiról megfogalmazott vezetési elveit. Emellett Zrínyinek a nemzeti szuverenitás védelméról és a magyar hadsereg modernizációjáról (szervezés, haditechnikai fejlesztés) írott gondolatai elméleti alapul szolgáltak a Magyar Honvédség modernizációja érdekében meghirdetett Zrínyi Honvédelmi és Haderófejlesztési Programnak. ${ }^{36}$

A Zrínyi Emlékév programsorozata a Magyar Honvédségben 2020. február 3-án az Nemzeti Közszolgálati Egyetem (NKE) Hadtudományi és Honvédtisztképzó Kar (HHK) napjának ünnepségével vette kezdetét, amit Zrínyi téli hadjáratának kiemelkedô sikere, az eszéki híd felégetése emlékére minden év február elején tartanak. A Zrínyi Miklós Laktanya és Egyetemi Campus udvarán álló Zrínyi-mellszobor koszorúzását követôen, a Karon évek óta múködő, Zrínyi munkásságát, különösen az általa, a török hódoltság területén épített Zrínyi-Újvár helyét, szerepét és 1664. évi ostromát módszeresen feltáró kutatócsoport vezetóje, Padányi József vezérórnagy, egyetemi tanár tartott előadást az elmúlt évek munkájáról, Zrínyi-Újvár sáncainak, az ostrom nyomainak lokalizációjáról. ${ }^{37}$ A vár jelentősége, hogy Magyarországon

32 Zrínyi Miklós 2020.

33 Szombathelyi Ferenc vezérezredes, a Honvéd Vezérkar Főnöke 1942. december 15-én kiadott útmutatójában fogalmazta meg: „A katonai tudomány szempontjából sem állunk hátrább másoknál. Zrínyink megelőzte Clausewitzet és Moltkét, és dacára annak, nem marad el mögöttük. Csak annyi szeretettel és megértéssel kell Ốt forgatni, mint azt a német klasszikusokkal tesszük. Akkor rajövünk arra, hogy a mi katonai tudományunk is klasszikus, noha kisebb is az irodalma, mint a németeké, és ami a fó, a mienk. Lehet, hogy a tál kisebb, amin az ételt kapjuk, de az étel ereje ugyanaz." Szombathelyi $1942,6$.

34 Pohl 2020. Zrínyi Miklós és öröksége c. fejezet, valamint az elóbbi önálló tanulmánykötetté bővített változatában: Zrínyi Miklós és öröksége. Szerk. Hausner Gábor. Sajtó alatt a Ludovika Egyetemi Kiadónál. Ezekben lásd Ruszin Romulusz: Zrínyi és a modern katonai vezetéselmélet és Sári Szabolcs: Pályakezdô tisztek kompetenciái (Zrínyi Miklós öröksége) címú tanulmányát.

35 A betûszó négy angol szó kezdóbetúiból áll össze. Jelentésük: V - Volatility: változékonyság, U Uncertainty: bizonytalanság, C - Complexity: komplexitás, A - Ambiguity: kétértelmúség. VUCA világ - Mi is ez pontosan?

http://dolgozzmagadon.blog.hu/2018/01/31/vuca_vilag_mi_is_ez_pontosan (Letöltés dátuma: 2020. 06. 09.)

36 Sticz, Seprődi-Kiss 2020, 6-7.

37 honvedelem.hu/hirek/hazai-hirek/zrinyi-miklos-emlekezete-a-hhk-kari-napjan.html (Letöltés dátuma: 2020. 06. 09.) 
az egyetlen, autentikus, Zrínyi Miklós által épített emlék. Tervezése, helyszínének, alakjának, védmúveinek, múszaki zárelemeinek elgondolása és kivitelezése Zrínyi szellemi terméke volt, amelyet így hadtudósi életmúve részeként kell tekintenünk. A 400. évfordulóra idózítve jelent meg az egyetemi kutatócsoport legfrissebb publikációja, a Zrínyi-Újvár-tanulmánykötet angol nyelvú változata, amely fontos és nem egyedüli mérföldköve Zrínyi Miklós munkássága nemzetközi elismertetésének. ${ }^{38}$

Zrínyi-Újvár jó példája a szervezett, évtizedes kutatómunka (kutatócsoport) és az emlékápolás, emlékezet közötti szoros összefüggésnek. A vár ugyanis egyik helyszíne és objektuma, alanya is lett az évfordulós megemlékezéseknek. 2020. június 10-én katonai tiszteletadással került sor a Somogy megyei Órtilos területén egykor állt erôsség régészeti feltárása során elókerült és utóbb rekonstruált, helyreállított várkút ${ }^{39}$ ünnepélyes átadására. A 400. évfordulóra idózített eseményen megjelent a Magyar Honvédség parancsnokának helyettese és a HM parlamenti államtitkára, aki beszédében kijelentette "Zrínyi Miklós igazi példakép a magyar katonáknak". 40 Zrínyi-Újvár utóbb, 2021 májusában ugyancsak a HM parlamenti államtitkára kezdeményezésére bekerült Magyarország történelmi emlékhelyeinek sorába, ${ }^{41} \mathrm{~s}$ ezzel várhatóan elhárul az (pénzügyi) akadály a vár kutatásának folytatása és helyszíni bemutatása elól.

A Honvédelmi Minisztérium Zrínyi Miklós születésének 400. évfordulója alkalmából 2020 tavaszán „Zrínyi Miklós élő öröksége” címmel alkotói pályázatot hirdetett professzionális képzómúvészek számára. A pályázat célja az volt, hogy Zrínyi Miklós történelmi alakjának megidézésével erôsítse a katonai hivatás imázsát, illetve a múvészeti alkotások felhasználásával növelje a honvédelem társadalmi elfogadottságát. ${ }^{42}$ A felhívásra számos pályázat érkezett, a zsúri által elismert legjobb alkotásokból a Stefánia Palota - Honvéd Kulturális Központ idószaki kiállítást rendezett, amelyet 2020. június 15 -július 24. között lehetett megtekinteni a Café Galériában. ${ }^{43}$ A képzómúvészeti alkotások 2021. november 23-tól Budapesten, a Honvédelmi Minisztérium Balaton utcai objektumának aulájában láthatók.

Zrínyi születésének évfordulóján a katonai hivatás fiatalok körében való népszerúsítése, a múlt magyar katonahôseinek és a jelenkori Magyar Honvédség megismertetése céljával a HM „1000 év katonái” címmel vetélkedót hirdetett a Zrínyi nevét viselő középfokú oktatási intézmények és a kadétprogramban részt vevô iskolák

38 Hausner, Németh 2020.

39 Költó, Vándor, Varga 2018.

40 Révész 2020. https://honvedelem.hu/hirek/a-magyar-honvedseg -parancsnokanak-helyettese/zrinyi-emlekezete.html (Letöltés dátuma: 2022. 01. 20.)

41 Révész 2021. https://honvedelem.hu/hirek/tortenelmi-emlekhely-lesz-zrinyi-ujvar.html (Letöltés dátuma: 2022. 01. 20.) Az ezt megörökítő emlékoszlop felállítására a tervek szerint idén márciusában kerül sor.

42 https://honvedelem.hu/hirek/kepzomuveszeti-palyazatot-hirdet-a-honvedelmi-miniszterium.htm (Letöltés dátuma: 2022. 01. 20.)

43 Kun-Orosz 2020. https://honvedelem.hu/hirek/kepzomuveszeti-palyazatot-hirdet -a-honvedelmi-miniszterium.htm (Letöltés dátuma: 2022. 01. 20.) 
9-11. évfolyamosai számára. ${ }^{44}$ A vetélkedôre több mint ötven csapat nevezett. A vírushelyzet miatt a kétfordulós vetélkedô első (szellemi) fordulójára 2020 ôszén-telén online került sor, amelynek a feladatai között a legnagyobb hangsúlyt (elérhetó pontszámot) a Zrínyi Miklós tevékenységéról készített központi feladatsor kapta. (A vetélkedó második, jelenléti fordulója 2021. szeptember 14-én Komáromban, a Monostori Erôdben zajlott a még versenyben lévő 7 fős csapatok és tanáraik részvételével.)

Mindezek mellett a HM még egy nagy jelentőségú lépést tett az évforduló kapcsán. Régi adósságot törlesztve, elkészült a 45/2020. (VIII. 14.) HM utasítás a Honvédelmi Értéktár létrehozásáról, amely szerint az ágazati Értéktár célja: a honvédelmi ágazatban azonosított nemzeti-honvédelmi és katonai értékek, valamint az ezekhez kapcsolódó értékek rendszerezése és gyújtése. ${ }^{45}$ 2020. december 17-én az Ágazati Értéktár Bizottság döntött a Padányi József által benyújtott javaslat alapján Zrínyi Miklós hadtudományi munkáinak Honvédelmi Értéktárba való felvételéról. ${ }^{46}$ Ezzel megnyílt az út Zrínyi hadtudományi munkáinak hungarikummá nyilvánítása elótt. ${ }^{47}$ Ruszin Romulusz, akkor még a Honvédelmi Minisztérium humánpolitikáért felelős helyettes államtitkára ezzel kapcsolatban feladatként határozta meg Zrínyi hadtudományi munkáinak új magyar és angol nyelvú kiadása elkészítését. Ennek megfelelóen jelent meg Zrínyi Miklós hadtudományi munkainak magyar nyelvú díszes kiadása, amelyet Ruszin Romulusz mutatott be a Honvédelmi Minisztériumban 2021. május 11-én tartott sajtótájékoztatón, ${ }^{48}$ majd novemberben a kötet angol fordítása is napvilágot látott. ${ }^{49} \mathrm{Ez}$ utóbbi ünnepélyes bemutatóján, 2021. november 23-án Benkó Tibor honvédelmi miniszter azzal nyújtotta át a kiadványt a publikumnak, hogy „,a most megjelent angol nyelvú kiadvány talán segít abban, hogy a világ megismerje Zrínyi Miklóst..., mint hadvezért, mint politikust, mint

44 Draveczki-Ury 2020. https://honvedelem.hu/hirek/hazai-hirek/ezer-ev-magyar-katonai -es-hostettei.html (Letöltés dátuma: 2022. 01. 20.) A versenyfelhívást lásd https:/honvedelem.hu/1000-ev-katonai.html (Letöltés dátuma: 2022. 01. 20.)

Érdekes, hogy a felhíváson megjelent egy Zrínyi Emlékév logó is, amely késóbb már sehol sem szerepelt a HM kommunikációjában.

45 https://honvedelem.hu/images/media/5fd0e08610a5f586588609.pdf (Letöltés dátuma: 2022. 01. 20.)

46 Antal 2020. https://honvedelem.hu/hirek/a-honvedelmi-ertektarba-kerultek -zrinyi-miklos-muvei.html (Letöltés dátuma: 2022. 01. 20.)

47 A hungarikum fogalmát és nyilvántartásba vételét a 2012. évi XXX. törvény a magyar nemzeti értékekról és a hungarikumokról szabályozza. Ez az értékek három csoportját nevezi meg: Települési, Megyei, Külhoni és Ágazati Értéktár, Nemzeti Értéktár és Hungarikum. A kiemelkedó nemzeti értékek adatainak nyilvántartása a Magyar Értéktárban történik. A Magyar Értéktárban nyilvántartott nemzeti értéknek hungarikummá nyilvánítására egyebek között az ágazati értéktárat múködtető, hatáskörrel rendelkezố miniszter tehet javaslatot az agrárpolitikáért felelós miniszter által vezetett 21 fös Hungarikum Bizottságnak. http://www.hungarikum.hu/hu/hungarikum-bizottsag (Letöltés dátuma: 2022. 01. 20.)

48 Zrínyi Miklós hadtudományi Munkái. 2021. A Zrínyi Miklós hadtudományi munkái a Honvédelmi Értéktárban c. bevezető tanulmányt írta Padányi József, szerk. Hausner Gábor. Lásd Zrínyi Miklós hadtudományi munkái egy kiadásban. 2021. május 12. https://kormany.hu/hirek/zrinyi-miklos -hadtudomanyi-munkai-egy-kiadasban (Letöltés dátuma: 2022. 01. 20.)

49 Miklós Zrínyi and His Works on Military Science. Trans. Kosztasz Panajotu, Boldizsár Eszes. József Padányi: The works of Miklós Zrínyi on military science in the Collection of National Defence Values. Ed. Gábor Hausner. Budapest: Zrínyi Kiadó, 2021. 
a hadtudományokkal foglalkozó kiváló személyiséget”. ${ }^{50}$ A könyvbemutatón részt vevô Benkő Tibor, Németh Szilárd és Simicskó István egybehangzóan hitet tett amellett, hogy „hungarikum mindaz, ami Zrínyi Miklós személyéhez, munkájához tartozik", és támogatják Zrínyi hadtudományi munkáinak hungarikummá nyilvánítását. ${ }^{51}$

A Honvédelmi Minisztériumnak a Zrínyi Miklós születése 400. évfordulója tiszteletére rendezett programjai a társadalom szélesebb köreit is elérték, és hozzájárultak nemcsak Zrínyi munkásságának, hanem a katonai hivatás népszerúsítéséhez is. A HM ebben számíthatott a Nemzeti Közszolgálati Egyetem Hadtudományi és Honvédtisztképző Karán múködő kutatócsoport és a honvédelmi ágazathoz kapcsolódó civil-szakmai szervezetek aktív közremúködésére. A jövô katonatisztjeit neveló Hadtudományi és Honvédtisztképzó Kar a Zrínyivel kapcsolatos új kutatási eredmények folyamatos publikálása mellett 2020. szeptember 29-én a Zrínyi Miklós Laktanya és Egyetemi Campuson „Zrínyiek a haza szolgálatában” címmel kiállítást rendezett professzor Padányi József vezérórnagy magángyújteményeinek legszebb darabjaiból. A Zrínyieket és a harcaikhoz köthetó helyszíneket bemutató 16-17. századi, eredeti rézkarcok, metszetek és térképek, valamint a Zrínyi-Újvár helyszíni kutatásai során felszínre került leletek néhány jellemzó darabja a honvédtisztjelöltek számára kívánta bemutatni és átélhetôvé tenni a Zrínyieknek a magyar függetlenségért vívott harcait. $^{52}$

E kiállítás megnyitóján került sor a már említett Zrínyi-Újoár. Egy 17 századi védelmi rendszer az oszmán hódoltság határán címú kötet ${ }^{53}$ bemutatójára, amelyet a Kar a Magyar Hadtudományi Társasággal közösen szervezett, s amelyen a munkát Szenes Zoltán, a Társaság elnöke méltatta. ${ }^{54}$

A Zrínyi Emlékév méltó megünneplésében a Honvéd Kulturális Egyesület is jelentôs szerepet vállalt. Egyrészt 2020-ban elkészített egy több mint másfél órás filmet a hadtudós és költő Zrínyi Miklós születésének 400. évfordulója alkalmából, 2020. október 6-án a Nemzeti Közszolgálat Egyetem Hadtudományi és Honvédtisztképző Karán Zrínyiról megrendezett konferencia elóadásaiból, ${ }^{55}$ másrészt kidolgozta egy Zrínyi Miklós 1664-es téli hadjáratának útvonalát megörökítô emléktáblasor létrehozásának tervét. A táblák elkészítése és elhelyezése a helyszíneken a Honvédelmi Minisztérium támogatásával 2021-ben kezdődött meg. Az elsô két

50 Takács 2021. honvedelem.hu/hirek/zrinyi-miklos-munkassaga-hungarikum.html (Letöltés dátuma: 2022. 01. 20.)

51 2021-ben Benkó Tibor honvédelmi miniszter benyújtotta a javaslatot Zrínyi Miklós hadtudományi munkái hungarikummá nyilvánítására, amelyet azonban a Hungarikum Bizottság 2021. decemberi ülésén elutasított.

52 A kiállításról magyar és angol nyelvú katalógus is készült: Zrínyiek a haza szolgálatában. Kiállitás a költốkatona Zrínyi Miklós születésének 400. évfordulójára. Rendezte Padányi József és Hausner Gábor. A katalógust szerkesztette Hausner Gábor. Budapest: NKE HHK, 2020.; Zrinyi: A family in the service of the country. An exhibition to commemorale the 400th anniversary of the birth of the poet and general, Miklós Zrinyi. Curated by József padányi, Gábor Hausner. Ed. Gábor Hausner. Budapest: NKE HHK 2020.

53 Hausner, Németh 2019.

54 Szenes 2020, 178.

55 https:/www.youtube.com/watch?v=aKILl1811uY\&feature=youtu.be (Letöltés dátuma: 2022. 01. 20.) 
emléktábla július 29-én Babócsán és Barcson került elhelyezésre, majd szeptember 2-án az ốrtilosi önkormányzattal együttmúködve, a hajdani Zrínyi-Újvár területén. ${ }^{56}$

\section{Összegzés}

Mint látható, a Zrínyi Miklós születésének 400. évfordulójára meghirdetett Zrínyi Emlékév egyik sajátossága, a megemlékezések és a tudományos eredmények publikálásának áthúzódása 2021-re. Az sem szokványos, hogy az emlékév nem kapott elkülönített költségvetési támogatást, hivatalos logo sem készült. Az emlékév ezen vonásai annál is feltúnóbbek, mert az eredetileg visszafogottra tervezett, „Nemzeti Összetartozás Éve" cím alá sorolt, ${ }^{57}$ ugyancsak 2020. évi Trianon-évfordulós programoknak, alkotásoknak és megemlékezéseknek nem szabott gátat sem a pandémia, sem a kormányzati emlékezet- és nemzetpolitika - ellenkezóleg. ${ }^{58}$

A Magyar Honvédség, a HM és az NKE HHK, illetve a honvédséghez kapcsolódó társadalmi szervezetek ennek ellenére méltó módon, sokféle formában (könyvkiadás, kiállítás, koszorúzás, emlékmú állítás stb.), a honvédelem résztvevoói és a társdalom szélesebb rétegei számára is transzparensen emlékeztek meg Zrínyi Miklós katonai és hadtudományi munkásságáról. A Zrínyi Emlékév legjelentósebb eredménye is (Zrínyi hadtudományi munkái Honvédelmi Értéktárba emelése, azok angol nyelvú fordítása és megjelenése, Zrínyi-Újvár történelmi emlékhelyek közé kerülése) a honvédelmi ágazathoz köthetók.

\section{FELHASZNÁLT IRODALOM}

1064/2020. (II. 28.) Korm. határozat a Nemzeti Összetartozás Éve megvalósításával kapcsolatos többlettámogatásra szolgáló költségvetési előirányzatról. Magyar Közlöny 2020 (31): 1101.

1064/2020. (II. 28.) Korm. határozat a Nemzeti Összetartozás Éve megvalósításával kapcsolatos többlettámogatásra szolgáló költségvetési elóirányzatról. Magyar Közlöny 2020 (31): 1101.

1121/2016 (III. 10.) Korm. határozat A „Zrínyi Miklós-Szigetvár 1566” emlékév megrendezésével összefüggó feladatokról. Magyar Közlöny 2016 (34.): 3738.

56 Az emléktáblákat dr. Négyesi Lajos ezredes, hadtörténész, a Honvéd Kulturális Egyesület alelnöke tervezte, és a süttối Békevári Kft. gyártotta le süttői vörös márványból $50 x 70 \mathrm{~cm}$-es nagyságban. A táblák egységes formátumban készültek, ezzel is hangsúlyozva az emléktábla sor összetartozását. Az ott történt események részletes leírása mellett a táblák állandó eleme a bal felsó sarokban szereplő Zrínyicímer és az érintett vár egykorú alaprajza. Továbbiakban táblát terveznek elhelyezni: Berzencén, Szigetváron, Pécsen, Siklóson, Baranyaváron, Dárdán, az eszéki híd északi végénél és Segesden.

57 Lásd erról Hamvay 2020. hvg360

https://hvg.hu/360/202004 trianonemlekev_schmidt_maria_nelkul_csendes_tarsak_az_elso_bekeev (A letöltés ideje: 2022. 01. 18.) A szomszédos országōkra tekintettē a Trianō̄emlékév helyett 2020-ra végül a politikailag kevésbé provokatív Nemzeti Összetartozás Évét hirdették meg.

58 A Nemzeti Összetartozás Évéhez kapcsolódó programok lebonyolítására a kormány több mint 10 milliárd Ft-ot biztosított. 1064/2020. (II. 28.) Korm. határozat a Nemzeti Összetartozás Éve megvalósításával kapcsolatos többlettámogatásra szolgáló költségvetési elóirányzatról. Magyar Közlöny 2020 (31): 1101. Ebból az összegból szinte megszámlálhatatlan kiállításra, koncertre, előadó estre, pályázatra és más eseményre került sor a határokon belül és kívül, és az emlékévhez kapcsolódóan számos tárgyiasult objekt (könyv, lemez, képzőmúvészeti alkotás, film) készült. 
Az Országgyúlés 51/2019. (XII. 12.) OGY határozata. Magyar Közlöny 2019 (201): 8794.

400 éve született Zrínyi Miklós - a Múvészeti Akadémia megemlékezése. 2020. május 3. https://www.mma.hu/rendezvenyeink?p_p_id=eventdetailedportlet_WAR_mmaportlet (A letöltés ideje: 2022. 01. 20.)

Antal Ferenc 2020. Zrínyi Miklós múvei. 2020. december 17. https:/honvedelem.hu/hirek/a-honvedelmi-ertektarba-kerultek-zrinyi-miklos-muvei.html (Letöltés dátuma: 2022. 01. 20.)

Bartha Tibor, Török Béla, Barkóczy Péter, Padányi József 2020. Zrínyi-Újvár régészeti lelóhelyén talált vasleletek anyagvizsgálatainak eredményei. Archeometriai Múhely 17 (2): 157-170.

Bene Sándor 2021. A harmadik szirén. Zrínyi Miklós költészete. (Osiris irodalomtörténet, monográfiák) Budapest: Osiris Kiadó.

Bene Sándor, Fodor Pál, Hausner Gábor, Padányi József (szerk.) 2017. Határok fölött. Tanulmányok a költô, katona, államférfi Zrínyi Miklósról. Budapest: MTA Bölcsészettudományi Kutatóközpont.

Bene Sándor, Pintér Márta Zsuzsanna (szerk.) 2021. Zrínyi Miklós és a magyarországi barokk költészet. 2021. Zrínyi Miklós és a magyarországi barokk költészet.

Tudományos konferencia Eger, 2020. szeptember 3-5. Eger: Líceum Kiadó.

Domokos György 2021a. Császári tábornok volt-e Zrínyi Miklós.

In Domokos György: Kö és tüz. Erődépitészet- és tüzérségtörténeti tanulmányok. 547-572. Budapest, 2021. https://militaria.hu/uploads/files/53369400_1636402558.pdf

Domokos György 2021b. The Construction and the Fall of Zrínyi-Újvár. In Uó: Kő és tüz. Erôdépitészet-és tüzérségtörténeti tanulmányok. 573-607. Budapest, 2021.

https://militaria.hu/uploads/files/53369400_1636402558.pdf (Letöltés ideje: 2022. 01. 20.)

Domokos György 2021c. Mi lett volna, ha..., avagy mit (nem) mentett meg Zrínyi Miklós 1664-ben. 2021. február 21. Ars Militaria blog

https://arsmilitaria.blog.hu/2021/02/22/mi_lett_volna_ha_avagy_hogyan_nem_mentette_meg zrinyi_miklos_a magyarorszagot_es_a

(Letöltés ideje: 2022 . 01. 20.)

Domokos György: et al. 2019. Raimondo Montecuccoli és múve. In Raimondo Montecuccoli: A magyarországi török háborúkról. Ford., jegyz. Domokos György, szerk. Hausner Gábor. (Pro Militum Artibus) 16-21. Budapest: Dialóg Campus Kiadó.

Gábor Hausner, Lajos Négyesi, József Padányi 2021. Novi Zrin u Mađarskim istraživanjima. In Dragutin Feletar (urednik): Utvrda Novi Zrin na Muri.

(Biblioteka Historia Croatica Knjiga 104.) 133-166. Čakovec, 2021.

Draveczki-Ury Ádám 2020. Ezer év magyar katonái és hőstettei. 2020. május 12. https:/honvedelem.hu/hirek/hazai-hirek/ezer-ev-magyar-katonai-es-hostettei.html (Letöltés dátuma: 2022. 01. 20.)

Hamvay Péter 2020. Orbán utasítására lesz megúszós a Trianon-évforduló. 2020. 01. 24. hvg360 https://hvg.hu/360/202004_trianonemlekev_schmidt_maria_nelkul_csendes_tarsak __az_elso_bekeev (A letöltés ideje: 2022. 01. 18.)

Harai Dénes 2017. Zrínyi mint magyar katonaeszmény a 19-20. században.

In Határok fölött. Tanulmányok a költő, katona, államférfi Zrínyi Miklósról. Szerk. Bene Sándor, Fodor Pál, Hausner Gábor, Padányi József. 401-418. Budapest: MTA Bölcsészettudományi Kutatóközpont.

Hausner Gábor 2013. Márs könyvet olvas. Zrínyi Miklós és a 17. századi hadtudományi irodalom.

(A Hadtörténeti Intézet és Múzeum könyvtára) Budapest: Argumentum Kiadó.

Hausner Gábor (szerk.) 2016. Zrínyi-album / Zrínyi Album. Budapest: Zrínyi Kiadó.

Hausner Gábor 2017. „Elméleti ellentéte Montecuccolinak?”

A Zrínyi-próza és az egyetemes hadtudományi irodalom:

In Határok fölött. Tanulmányok a költő, katona, államférfi Zrínyi Miklósról. Szerk. Bene Sándor, Fodor Pál, Hausner Gábor, Padányi József. 95-122. Budapest: MTA Bölcsészettudományi Kutatóközpont.

Hausner Gábor, Németh András (szerk.) 2019. Zrinyi-Újuár. Egy 17 századi védelmi rendszer az oszmán hódoltság határán. Budapest: Dialóg Campus Kiadó.

Hausner Gábor, Padányi József (szerk.) 2012. Zrínyi-Újvár emlékezete. Budapest: Argumentum Kiadó.

Hausner, Gábor; Németh, András (Ed.) 2020. Zrínyi-Újvár. A Seventeenth-Century Border Defence System on the Edge of the Ottoman Empire. Budapest: Dialóg Campus. 
Hausner, Gábor; Négyesi, Lajos; Padányi, József 2012. Novi Zrin u svjetlu izvora i straživanja terena. In Sándor Bene, Zoran Ladić, Gábor Hausner (ur.): Susreti dviju kultúra. Obitelj Zrinski u hrvatskoj i mađarskoj povijesti. 189-217. Zagreb, Matica Hrvatska.

honvedelem.hu/hirek/hazai-hirek/zrinyi-miklos-emlekezete-a-hhk-kari-napjan.html (Letöltés dátuma: 2020. 06. 09.)

http://nski.hu/dijazottak.html (A letöltés ideje: 2022. 01. 20.)

http://www.hungarikum.hu/hu/hungarikum-bizottsag (Letöltés dátuma: 2022. 01. 20.)

https://doi.org/10.26080/krrmkozl.2018.5.195

https://honvedelem.hu/1000-ev-katonai.html (Letöltés dátuma: 2022. 01. 20.)

https://honvedelem.hu/hirek/kepzomuveszeti-palyazatot-hirdet-a-honvedelmi-miniszterium.htm (Letöltés dátuma: 2022. 01. 20.)

https://honvedelem.hu/images/media/5fd0e08610a5f586588609.pdf (Letöltés dátuma: 2022. 01. 20.)

https://kormany.hu/hirek/petofi-emlekev-a-kormany-9-milliard-forintos-tamogatast-biztosit (A letöltés ideje: 2021. 08. 16.)

https://mnm.hu/hu/esemenyek/kiallitas/kerekasztal-beszelgetes-zrinyi-miklos-halalanak-korulmenyeirol (Letöltés ideje: 2022. 01. 20.)

https://mnm.hu/hu/esemenyek/muzeumi-elet/filmbemutato-zrinyi-miklos-ravatala-folott -elo-tortenelem-virtualis-terben (Letöltés ideje: 2022. 01. 20.)

https://mta.hu/tudomany_hirei/tobb-orszag-szolgalataban-a-politikus-katona-es-kolto-iro -zrinyi-miklos-identitasai-110242 (A letöltés ideje: 2021. 08. 16.)

https://mta.hu/tudomany_hirei/tobb-orszag-szolgalataban-a-politikus-katona-es-kolto-iro -zrinyi-miklos-identitasai-110242 (A letöltés ideje: 2021. 08. 16.)

https:/www.youtube.com/watch?v=aKILl1811uY\&feature=youtu.be (Letöltés dátuma: 2022. 01. 20.)

Klaniczay Tibor 1964. Zrínyi Miklós. Második, átdolg. kiad. (Irodalomtörténeti könyvtár 14.) Budapest: Akadémiai Kiadó.

Költố László, Vándor László, Varga Máté 2018. Órtilos - Zrínyi-Újvár régészeti feltárása (2016-2017). A Kaposvári Rippl-Rónai Múzeum Közleményei (5): 195-202.

Költő László, Négyesi Lajos, Bertók Gábor, Padányi József, Szabó András 2014. Zrínyi-Újvár sáncának lokalizálása, feltárása és rekonstrukciója. Hadtörténelmi Közlemények 127 (1): 91-102.

Kun-Orosz Adrienn: Zrínyi Miklós élő öröksége. 2020. június 15. https:/honvedelem.hu/hirek/kepzomuveszeti-palyazatot-hirdet-a-honvedelmi-miniszterium.htm (Letöltés dátuma: 2022. 01. 20.)

mhttps://hungarianhub.com/listing/unnepi-rajz-es-esszepalyazat-a-magyar-zaszlo-es -cimer-megunneplesere-nemzetstrategiai-kutatointezet/ (A letöltés ideje: 2021. 08. 16.)

Miklós Zrínyi and His Works on Military Science 2021. Trans. Kosztasz Panajotu, Boldizsár Eszes. József Padányi: The works of Miklós Zrínyi on military science in the Collection of National Defence Values. Ed. Gábor Hausner. Budapest: Zrínyi Kiadó.

Nagy Levente, Hausner Gábor 2011. Raimondo Montecuccoli és a magyarok. Hadtörténelmi Közlemények 124 (3): 679-740.

Négyesi Lajos, Németh András, Padányi József, Szabó András 2020. Zrínyi-Újvár kutatása a hadirégészet eszközeivel. I. rész Haditechnika 54 (6): 64-68.

Négyesi Lajos, Németh András, Padányi József, Szabó András 2021. Zrínyi-Újvár kutatása a hadirégészet eszközeivel. II. rész Haditechnika 55 (1): 67-70.

Padányi József 2021. Padányi József, Zrínyi Miklós hadtudományi munkái a Honvédelmi Értéktárban. In Zrínyi Miklós hadtudományi munkái 7-27. Budapest: Zrínyi Kiadó.

Pálffy Géza 2016. Zrínyi Miklós nagy napja. Az 1663-1664. évi török háború egyik meghatározó eseménye: a vati hadimustra 1663. szeptember 17-én.

Budapest -Pápa: MTA Történettudományi Intézet-Jókai Mór Városi Könyvtár.

Pálffy Géza 2007. Egy horvát-magyar főúri család a Habsburg Monarchia nemzetek fölötti arisztokráciájában. A Zrínyiek határokon átívelő kapcsolatai.

In Bene Sándor, Hausner Gábor (szerk.): A Zrínyiek a magyar és a horvát históriában. 39-66. Budapest: Zrínyi Kiadó. 
Pálffy Géza 2017. Költő és hadvezér? A politikus, katona és költoo-író Zrínyi Miklós lojalitásai és identitásai. In Bene Sándor, Fodor Pál, Hausner Gábor, Padányi József (szerk.): Határok fölött. Tanulmányok a költő. katona, államférfi Zrínyi Miklósról. 15-26.

Budapest: MTA Bölcsészettudományi Kutatóközpont.

Pohl Árpád (szerk.) 2020. Biztonság és honvédelem. (Fenntartható biztonság és társadalmi környezet tanulmányok II.) Budapest: Ludovika Egyetemi Kiadó.

Révész Béla 2020. Zrínyi emlékékezete. 2020. június 10. https://honvedelem.hu/hirek/a-magyar-honvedseg-parancsnokanak -helyettese/zrinyi-emlekezete.html (Letöltés dátuma: 2022. 01. 20.)

Révész Béla 2021. Történelmi emlékhely lesz Zrínyi-Újvár. 2021. május 5. https://honvedelem.hu/hirek/tortenelmi-emlekhely-lesz-zrinyi-ujvar.html (Letöltés dátuma: 2022. 01. 20.)

Rónai Horváth Jenő 1889. Gróf Zrínyi Miklós a költô és hadvezér hadtudományi elvei. Hadtörténelmi Közlemények 2 (1): 1-19.

Rónai Horváth Jenő 1891. Bevezetés. Zrínyi Miklós mint hadvezér és mint hadtudományi író. In: Gróf Zrínyi Miklós a költố és hadvezér hadtudományi munkái.

S. a . r. és jegyz. Rónai Horváth Jenó. 7-60. Budapest.

Sticz László, Seprődi-Kiss Árpád 2020. A Magyar Honvédség képességfejlesztése, egy korszerú haderô megteremtése. Hadtudomány 30 (4): 3-19.

Suhai Pál 2020. Tollal és kézzel. Zrínyi Miklós költói és prózai müvei. Budapest: Balassi Kiadó.

Szenes Zoltán 2020. Hausner Gábor - Németh András (szerk.): Zrínyi-Újvár. Egy 17 századi védelmi rendszer az oszmán hódoltság határán. (Könyvismertetés) Hadtudomány 30 (4): 178.

Szombathelyi Ferenc 1942. Konkrét felsố vezetési elveim. Budapest.

Takács Vivien 2021. Zrínyi Miklós munkássága hungarikum. 2021. november 23. honvedelem.hu/hirek/zrinyi-miklos-munkassaga-hungarikum.html (Letöltés dátuma: 2022. 01. 20.)

Végh Ferenc 2017. Zrínyi Miklós és Péter, a törökellenes határvédelem szervezői:

A Muraköz védelmi rendszere a 17. század közepén.

In Bujdosné Pap Györgyi, Fejér Ingrid, H. Szilasi Ágota (szerk.): Várostromok és Közép-Európa: Zrínyi Miklós (1620-1664) korában. 217-246. Eger, Dobó István Vármúzeum.

Végh Ferenc 2020. A „Magyar Márs” árnyékában. Az ismeretlen Zrínyi Péter. Hadtörténelmi Közlemények 133 (4): 805-825.

Végh Ferenc 2021. „Zrínyiek a határok védelmében. A muraközi uradalom hadszervezete a kora újkorban" c. habilitációs dolgozat. https://kozepkor.tti.btk.pte.hu/hu/tartalom/habilitacios_ertekezes_tezisei_dr_vegh_ferenc (Letöltés ideje: 2021. 09. 30.)

VUCA világ - Mi is ez pontosan? http://dolgozzmagadon.blog.hu/2018/01/31/vuca_vilag_mi_is_ez_pontosan (Letöltés dátuma: 2020. 06. 09.)

Zrínyi Miklós hadtudományi munkái egy kiadásban. 2021. május 12. https://kormany.hu/hirek/zrinyi-miklos-hadtudomanyi-munkai-egy-kiadasban (Letöltés dátuma: 2022. 01. 20.)

Zrínyi Miklós hadtudományi munkái. 2021. Zrínyi Miklós hadtudományi munkái. A bevezetố tanulmányt írta Padányi József, szerk. Hausner Gábor. Budapest: Zrínyi Kiadó.

Zrínyi Miklós 2020. Vitéz hadnagy. Az előszót írta Benkő Tibor. Budapest: HM Zrínyi Nonprofit Kft., 2020.

Zrinyi: A family in the service of the country. An exhibition to commemorale the 400th anniversary of the birth of the poet and general, Miklós Zrínyi. Curated by József padányi, Gábor Hausner. Ed. Gábor Hausner. Budapest: NKE HHK 2020.

Zrínyiek a haza szolgálatában. Kiállitás a költó-katona Zrínyi Miklós születésének 400. évfordulójára. 2020. Rendezte Padányi József és Hausner Gábor. A katalógust szerkesztette Hausner Gábor. Budapest: NKE HHK. 